\title{
Does the Religious Coping has an Effect on Perceived Stress?
}

\author{
Muhamad Nanang Suprayogi ${ }^{1}$, and Rodiah Aljufri ${ }^{2}$ \\ \{msuprayogi@binus.edu ${ }^{1}$, rodiahaljufri@yahoo.com ${ }^{2}$ \} \\ Department of Psychology, Faculty of Humanity, Bina Nusantara University, Jakarta ${ }^{1}$
}

\begin{abstract}
There are various coping stress strategies, one of the oftenly used coping stress strategy in Indonesia is religoius coping. The purpose of this study was to examine the effect of religious coping on reducing stress. The study applied a quantitative method using multiple regression analysis. The current study involved 354 participants in the congregation of one of the religious leader in Indonesia, named Halimah Alaydrus. The results of this study revealed that there is a significant effect of religious coping on reducing stress $(\mathrm{r}$ square $=0.157$, sig. $<0.001)$. As to the finding of this study, it is recommended to apply the religious coping in releasing the stress.
\end{abstract}

Keywords: Religious coping, Stress, Human life, Problem.

\section{Introduction}

Stress is a common problem that does occur in human life and it is an inevitable. Every person will face and experience the stress [1]. The stress can occur in each of human development phases, including in the phase of early adulthood [2]. This phase is one of the vulnerable phases of human life which is the period with a lot of problems that can cause stress, a lot of emotional tension and changes in everyday life. The stress is endanger, and therefore need to be released. One of the psychological factors that can reduce or even eliminate stress is through coping stress [3].

\subsection{Stress}

Stress has three different meanings [4], first, stress seen as a stimulus; is considered as external factors, interpreted as stimulus originating from the environmental situations which felt so pressing. Second, stress seen as a response; is a stress that is seen as a response or body response that is specific to the cause of stress, which affects a person's psychological state and perceived tension, this considered as an internal factor. Third, seen as a physical body stress; is a stress that is no longer seen as a stimulus or response, but seen as a process, which destroys and causes problem. Given the broad area of study on stress, in this study the researcher will focus on the stress as a stimulus.

Stress as a stimulus is stress experienced by person that comes from the stressful environmental situation [5]. The person is simply receive the stimuli without any prior process of assessment [6]. Furthermore according to Bartlett [7], various pressures events that are 
occur in the surrounding environment can be a source of stress. The stimulus can be the causes and determinants of various health problems if they occur largely and frequently. Bartlett also explains that stress as a stimulus are not focused on other aspects, but the focus are more on the sources of stress, and therefore the source of stress is known as "stressors" [8]. In accordance with the given name as a stressors, the stressor act as trigger, giving stimuli and encouragement to someone and therefore the stress occurs.

Stress is also defined as an individual response toward the stressors, i.e. in the environment or events that threaten a person and become a burden in an individual's coping abilities [9]. Furthermore Lazarus \& Folkman [10] also explains that the stressor on stress as a stimulus are contains of a variety of things that occur in the life of a person with a stressful nature.

Based on the description above, the researcher uses the theory of Cohen \& Williamson [11] to explain stress, which is interpreted as a description of the extent to which an individual evaluates events in his/her life that tend to be sudden and unpredictable, uncontrollable, beyond one's supervision and beyond the standards or limits that should and which usually occur in a person's life. As commonly known, the stressors in life cannot be predicted when it will come, and also cannot be controlled. The stress are also inevitable, the person cannot choose him/her self to be free from stressors in their life. Furthermore, the stress also cannot be known the the term of amount, is it exceeds the limits of one's ability or not.

\subsection{Religious coping}

Coping is the ability of person's needs to overcome, resolve and deal with a threatening event or situation [12]. Moreover, according to Lazarus \& Folkman [13] coping is a person's ability to manage the events, circumstances, and situations in order to solve the life's problems and find the solutions and ways to reduce the stress. Coping can also be explained as a person's process in regulating the differences in resources possessed by demands being faced in stressful situations [14]. Furthermore Stone \& Neale, [15] conducted a study of the measurement of coping behavior commonly used by person in living their daily lives. It was found that there were eight behaviors that usually person carried out when facing the problems, these are 1). Doing damage to himself or to others, 2). Limiting the situation and circumstances, 3). Direct action to solve the problems, 4). Catharsis of the problems 5). Accept the problems, 6). Seek social support from the neighbors or surrounding 7). Relax, and $8)$. Religion, i.e. the effort to get closer to God the almighty.

In line with the research on religion, Wong \& Wong, [16] in their research found that in this life there are many people who try to solve various problems by getting closer to the Supreme Regulatory of life, which is the God almighty that perfectly creates, makes and regulates the universe. Through a self-approach to God almighty, person have a new hope, and he/she believe that the problem will be solved. The phenomenon of resolving life problems by involving God through a religious approach, is one of the coping strategies named as religious coping.

By using religious coping strategies, person have different views, he/she feels trust and has strong beliefs that there is a very large force that exists in his/her life. Through the religious approach, person believe in the existence of a great God and the great regulator of life who has the greatest power in his/her life. 
Pargament explains that religious coping is one type of coping that can be used when person facing a problem. Religious coping is a sense and an effort of a person who focuses and involves religious elements such as worship and religious activities that can be used in solving problems, and used to face the events or situations that can cause stress [17]. Furthermore, research conducted by Compton, [18] explains that the faiths and beliefs of person related on his/her religion are useful and deterrent to stress.

According to Marsella, Wong \& Wong, [19]. suggests that health scientists should note the fact that for many people, religion is often considered important in one's efforts to achieve physical and psychological health, therefore religious coping should be seen contextually. Moreover, Marsella, et al, [20] also explains on the study of the benefits of the religious coping that over past six years there have been a large number of scientific studies on religious coping that focus on the results of research linked to various forms of mental and physical health, and the results obtained as a whole show the fact that religious coping is a beneficial way that can be used by someone in an effort to deal with mild stress to severe stress that occurs in everyday life. Based on the theories and phenomena above, it can be seen that there are religious coping effects on stress. Therefore, the following hypothesis is formed, there is a significant effect of religious coping on perceived stress.

\section{Manuscript preparation}

\subsection{Measures}

This This study used a quantitative approach. The data collected through the questionnaire distributed online. The participants receive the link of the questionnaire to be filled in. The author then retrieves the data from the responses of the participants. The process of the data collection and the using the quantitative approach following to the steps as described by Gravetter \& Forzano, [21].

As for the questionnaire, this study used the research instruments of Religious Coping Scale (RCOPE) from Pargament, Koenig \& Perez [22]. The RCOPE are contains of 26 items, with 4 Likert scales (strongly agree, agree, disagree, strongly disagree). The RCOPE has 5 dimensions, those are 1). Meaning which has 5 items, 2). Comfort which has 5 items, 3). Life transformation which has 6 items, 4). Control that has 5 items, and 5). Intimacy which has 5 items.

This study also used the Cohen PSS-10 (Perceived Stress Scale-10) Cohen \& Williamson, [23] as the research instrument for the stress variable. The PSS10 consists of 10 items with 5 Likert scales (never, almost never, sometimes, often, very often). The PSS10 is a self-report questionnaire that can evaluate the stress of the participants.

The research respondents in this study were members of the congregation of Halimah Alaydrus who had attended the study at least three times. Researchers conducted data collection by distributing questionnaires through online.

\subsection{Participants}

The researcher obtained 354 participants with an age range of 20-40 years with $(\mathrm{M}=$ $90.74, \mathrm{SD}=5.41)$. Based on the occupation, the majority of participants are housewives $=126$ participants $(35.6 \%)$, followed by employees $=111$ participants $(31.4 \%)$, students $=64$ 
$(18.1 \%)$, and entrepreneurs $=53$ participants $(15 \%)$. Based on the marital status, the majority of participants are married $=176$ people $(49.7 \%)$, not married $=164$ people $(46.3 \%)$ and divorce $=14$ people $(4 \%)$.

\subsection{Data analysis}

The research data was analyzed using multiple regression. We use the multiple regression as religious coping has 5 dimensions. We further analyze the effect of each dimension of religious coping, which is the total score of the five dimension (Meaning, Control, Comfort, Intimacy, Life Transformation) to the perceived stress.

\section{Result}

The table 1 below, showing the descriptive results of the research variables.

Table 1. Descriptive results of the research variables.

\begin{tabular}{lccccc}
\hline \multicolumn{1}{c}{ Variabel } & N & Min & Max & Mean & SD \\
\hline Meaning & 354 & 11,00 & 20,00 & 15,89 & 1,81 \\
Control & 354 & 13,00 & 20,00 & 18,00 & 1,40 \\
Comfort & 354 & 12,00 & 20,00 & 18,05 & 1,38 \\
Intimacy & 354 & 12,00 & 20,00 & 16,98 & 1,52 \\
Life Transformatif & 354 & 17,00 & 24,00 & 21,81 & 1,57 \\
Religious Coping & 354 & 72,00 & 102,00 & 90,74 & 5,41 \\
Stres & 354 & 2,00 & 31,00 & 14,92 & 5,14 \\
\hline
\end{tabular}

Based on the data provided in table 1, it can be seen that the lowest mean score is on dimension meaning, while the highest score is on dimension life transformation. We further categorize the level for each dimensions. We use the mean score as a base line. The score that below the mean score is categorize as low level, while the score that above the mean score is categorize as high level. In table 2, we can see the category level for each dimension from all the participants.

Table 2. Descriptive category of the level religious coping and it's dimensions.

\begin{tabular}{llcc}
\hline \multicolumn{1}{c}{ Dimensions } & Category & Frequency & $\begin{array}{c}\text { Percentage } \\
(\%)\end{array}$ \\
\hline Meaning & Low & 147 & 41,5 \\
& High & 207 & 58,5 \\
Control & Low & 209 & 59,0 \\
& High & 145 & 41,0 \\
Comfort & Low & 191 & 54,0 \\
& High & 163 & 46,0 \\
Intimacy & Low & 133 & 37,6 \\
& High & 221 & 62,4 \\
Life Transformatif & Low & 109 & 30,8 \\
& High & 245 & 69,2 \\
Religious Coping & Low & 158 & 44,6
\end{tabular}


Based on the results in table 2, it can be seen that there are 147 participants $(41.5 \%)$ with low level on meaning dimension and 207 people $(58.5 \%)$ with high level on meaning dimension. Furthermore, the on the control dimension, the low level is 209 people $(59.0 \%)$ and there are 145 people with high level $(41.0 \%)$. On the comfort dimension, 191 people (54.0\%) have low level, and 163 people (46.0\%) have high level.

In the intimacy dimension there were 133 people (37.6\%) with a low level and 221 people $(62.4 \%)$ with a high level. In the life transformation dimension there are 109 people $(30.8 \%)$ with a low level and 245 people $(69.2 \%)$ with a high level. In aggregate, it can be seen on the religious coping variables there are 196 people (55.4\%) with high level and there are 158 people with low level category (44.6\%).

Furthermore, we analyze the effect of religious coping to the perceived stress using the multiple regression method. The results of the analysis can be seen on the table below.

Table 3. Regression analysis result.

\begin{tabular}{lccccc}
\hline \multirow{1}{*}{ Model } & \multicolumn{5}{c}{ ANOVA $^{\text {a }}$} \\
& $\begin{array}{c}\text { Sum of } \\
\text { Square }\end{array}$ & DF & Mean & F & Sig \\
& 1466,46 & 5 & 293,29 & 12,94 & $.000^{\mathrm{b}}$ \\
\hline Regression & 7889,32 & 348 & 22,67 & & \\
Residual & 9355,79 & 353 & & & \\
Total & & & &
\end{tabular}

a. Dependent Variable: Stres

b. Predictors: (Constant), Life Transformation, Meaning, Intimacy, Comfort, Control

Based on table 3 , it can be seen that the p value (Sig) is .000 . and it is $<0.05$. This means that there is a significant effect of on the of religious coping on perceived stress in the congregation of Halimah Alaydrus.

Moreover, to see the amount of the effect of religious coping to the stress coping, we further see the model summary analysis as depicted on table below.

Table 4. Regression analysis model summary result.

\begin{tabular}{cccc}
\hline \multirow{2}{*}{ Model R } & \multicolumn{2}{c}{ Model Summary } \\
R Square & $\begin{array}{c}\text { Adjusted } \\
\text { R Square }\end{array}$ & $\begin{array}{c}\text { SE of the } \\
\text { Estimate }\end{array}$ \\
\hline, $396^{\mathrm{a}}$ &, 157 &, 145 & 4,76 \\
\hline
\end{tabular}

a. Predictors: (Constant), Life Transformation, Meaning, Intimacy, Comfort, Control

From table 4 we can see that, the value of $R$ Square $\left(R^{2}\right)$ is 0.157 or $15.7 \%$. This shows that model of religious coping (meaning, control, comfort, intimacy, and life transformation) provide the effect on perceived stress by $15.7 \%$. Therefore, the remaining $84.3 \%$ is influenced by other factors.

Going into detail, we further analyze each of the religious coping dimensions. From 5 dimensions we can see that certain dimensions have significant effect to the religious coping, while the other dimensions have no significant effect. The detail can be seen in table 5 . 
Table 5. Effect of each dimension of the religious coping to the perceived stress.

\begin{tabular}{lccccc}
\hline \multicolumn{1}{c}{ Model } & B & SE & Beta & t & Sig. \\
\hline (Constant) & 46,68 & 4,33 & & 10,79 &, 00 \\
Meaning &,- 283 &, 15 &,- 10 & $-1,88$ &, 06 \\
Control &,- 848 &, 23 &,- 23 & $-3,63$ &, 00 \\
Comfort &,- 317 &, 23 &,- 08 & $-1,39$ &, 17 \\
Intimacy &,- 417 &, 19 &,- 12 & $-2,15$ &, 03 \\
Life Transformatif &, 037 &, 20 &, 01 &, 19 &, 85 \\
\hline
\end{tabular}

a. Dependent Variable : Stres

The data shows that only 2 dimension have significant effect to the perceived stress. Those are Control dimension $(\mathrm{p}<0.005)$, and Intimacy dimension $(\mathrm{p}<0.005)$.

\section{Discussion}

The results of the study showed that religious coping proved to have a significant effect on perceived stress in the congregation of Halimah Alaydrus. These results are in line with the research on the benefits and the effectiveness of the religious coping conducted by McMahon \& Biggs, [24] which proven that individuals who use religious coping in dealing with various problems that occur in their lives will tend to be calmer and not easy to feel stressed. Furthermore, study of Ellison \& Taylor, [25] revealed that the religious coping is very popular and effective for a particular group within the community. The study also showed that the worship activities such as praying and religious activities such as recitation of the holly book seemed very valuable in dealing with stress.

The results of this study also in line with explanation of Pargament about religious coping. Pargament explained that religious coping strategies tend to be used when someone has high desires that cannot be obtained from humans, or when someone feels that he/she no longer has the ability to deal with the reality of life. So that the individual can divert his weaknesses to an unlimited power that he/she trusts and believes in, to get the power to be able to face the difficult reality [26]. In this study religious coping variables generally affect the perceived stress. Chen, \& Koenig [27] research, explains that religious coping has a relationship with stress reduction.

As to the dimension of religious coping, we see that only two dimensions (Control and Intimacy) which have significant effect to the perceived stress. The other three dimensions (Meaning, Comfort, Life Transformation) have no significant effect. On meaning dimensions, it does not significantly effect stress in this study. Meaning is a religious coping method in the search for meaning. This is related to individual efforts to find meaning in life. Geertz, [28] explains that religion plays a fundamental role as a key in the search for meaning that someone does in their lives in trying to deal with problems and suffering that occur in life. Meaning allows someone to change and adjust the previous expectations that someone has in certain situations to change the view on him. It can be concluded that a person has a will in adjusting previous expectations for a particular situation in changing his view of himself apart from life not always as expected, this is in accordance with the explanation of Cohen \& Williamson, [29] describing the stress, which is interpreted as an illustration about the extent to which an individual assesses the events in his life that tend to be sudden and unpredictable, 
uncontrollable, out of someone's control and beyond the standards or limits that should and which usually occur in one's life, with greater coverage and overloading. Because stressors in life cannot be predicted when the time will come, it cannot be controlled i.e. someone cannot choose to be released from stressors in life.

In the control dimension, it has significant effect on stress. This means that the higher the control a person has, the lower the stress level will be. Control, namely as a religious coping method in the control of an event and as a search for power. This is related to individual efforts in applying religious rules as a basis for living life, in order to achieve harmony and goals in a balanced and good life, to achieve mutual benefit. Because if living without control is certain and directed, there will be many people who make mistakes in life. This is in line with the research of Pargament, Koenig \& Perez, [30] which explains that the controls contained in religion have a negative relationship with stress. Furthermore, Kliewer \& Sandler, [31] in his study found that the controls contained in religion as one of the types of selfsystem processes that have been proven to affect stress in one's life. This is also in line with the frequent delivery by Halimah Alaydrus that if someone has a big problem in his life then calm down because there is a Great God, your big problem will be small before the Greatest God.

The comfort dimension does not significantly effect the perceived stress in this study. Kovel, [32] explained that religion was designed to reduce the fear someone had about life in the world which was full of uncertainties in life, where calamities, disasters, and problems in life could strike anyone, anytime and anywhere. So it is very difficult to separate comfort from religious coping that has a spiritual function.

In intimacy dimensions it has negative effect to perceived stress. This means that the higher the intimacy, the lower the level of stress experienced. Intimacy is to establish relationships with the community in a social environment and closeness to God. This is related to the efforts of individuals to establish relationships with fellow humans in order to achieve closeness with God. Papalia, Diane, Olds, Sally \& Feldman, [33] explains about intimacy that intimacy is the ability to be close to other people such as in friendship or community members. Furthermore, intimacy can be interpreted as a form of sharing between two people or more in the form of feelings and also in the form of action. This is in line with observations made by researchers in the study of Halimah Alaydrus. The congregation of Halimah Alaydrus is always trying to be close to Halimah Alaydrus, this is because the congregation can easily ask for advice, direction and prayer in order to become a better human being who is loved by God. Their question comes from why the problem exists and how to be sincere in accepting all of God's destiny, and what they do in doing good together and giving advice to each other to get closer to God.

Furthermore, life transformation does not significantly effect the perceived stress. Life transformation is a method of religious coping in search and serving changes in life. This is related to individual efforts to achieve prosperity and mutual benefit in order to achieve peace, justice and shared prosperity. But as what was explained by Cohen \& Williamson, [34] that events in life experienced by someone tend to be sudden and unpredictable, uncontrollable, outside of someone's supervision and beyond the standards or limits that should and which usually occur in life someone, with greater coverage and overloading. This then makes it difficult for the congregation to achieve prosperity and benefit together to achieve peace and common prosperity, because indeed every human being has problems in their respective lives which are not necessarily the time of their arrival, which sometimes exceeds the capacity of a person, which sometimes affects many people at once. In the congregation of Halimah Alaydrus who indeed came from different environments, economic backgrounds, different 
social and educational statuses, different origins, different ages, different types of work and different marital statuses that made the life transformation in this study not significant effect.

Religious coping is an effort to get closer to God in an effort to deal with and solve a problem someone has. So that in this case the researcher sees that the higher the religious coping someone has, the greater the likelihood that a person can easily reduce or even eliminate the stress that is felt, because as has been previously discussed that religious coping is one of the efforts or ways that someone uses to deal with and solve problems that are being owned by getting closer to God, involving God in solving problems, and even giving up all matters to God.

\section{Recommendation}

Based on the results of the research data analysis, the conclusions that can be drawn from this study are that there is a significant effect of religious coping (meaning, control, comfort, intimacy, and life transformation) to perceived stress on the congregation of Halimah Alaydrus with a contribution of $15.7 \%$.

The researcher has some practical suggestions to the congregation for the study of Halimah Alaydrus to maintain the religious activities on a regular basis to help the people in avoiding stress, and it is suggested to have regular counseling with Halimah Alaydrus. For future study, it is recommended to increase the number of research participants so that they become larger and can cover all elements of the population in a balanced manner, and therefore the results of the research obtained can better reflect the actual conditions and broader results can be generalized. It also suggested to develop and use other variables that are related to the stress.

\section{Acknowledgements}

We would like to convey our thank to Halimah Alaydrus. She has allowed us to do the research in her congregation, and therefore this study can be done effectively.

\section{References}

[1] Kupriyanov, R., \& Zhdanov, R. The Eustres Concept: Problems and Outlooks. 11 (2), 179185. (2014).

[2] Hurlock, E. B. Developmental Psychology: A LifeSpan Approach . United States: McGraw Hill College. (1999).

[3] Nevid, J. S., Rathus, S. A., \& Greene, B. Psikologi Abnormal. Jakarta: PT. Penerbit Erlangga. (2002).

[4] Rice, P. L. Stres and Health. USA: International Thomson Publishing Company. (1999).

[5] Bartlett, D. Stres: Perspectives and processes. Philadelphia, USA: Open University Press. (1998).

[6] Staal, M. A. Stres, cognition, and human performance: A literature review and conceptual framework. Diambil kembali dari http://humanfactors.arc.nasa.gov/web/library/publications/publications.php. (2004).

[7] Bartlett, D. Stres: Perspectives and processes. Philadelphia, USA: Open University Press. (1998).

[8] Bartlett, D. Stres: Perspectives and processes. Philadelphia, USA: Open University Press. (1998).

[9] King, L. A. Science of psychology: an appreciative view (2 ed.). United States: McGraw Hill Higher Education. (2010). 
[10] Lazarus, R. S., \& Folkman, S. Stres, Apraisal and Coping. New York: Springer Publishing Company. (1984).

[11] Cohen, S., \& Williamson, G. Perceive Stres in a Probability Sample of the United States. Dalam S. Spacapan, \& S. Oskamp, The Social Psychology of Health. Newbury Park, CA, Sage. (1988).

[12] Aronson. (2014). Social Psychology (8 ed.). United States, Pearson.

[13] Lazarus, R. S., \& Folkman, S. Stres, Apraisal and Coping. New York: Springer Publishing Company. (1984).

[14] Sarafino, E. P. Health psychology: biopsychosocial interactions (7 ed.). USA: John Wiley \& Sons, Inc. (2011).

[15] Stone, A. A., \& Neale, J. M. New measure of daily coping: Development and primary result. Journal of Personality and Social Psychology, 46(4), 492906. (1984).

[16] Wong, P. T., \& Wong, L. C. Handbook of multicultural perspectives on stres and coping. New York: Springer Science+Business Media, Inc. (2006).

[17] Pargament, K. I. The Psychology of Religion an Coping: Theory, Research, and Practice. New York: The Guildford Press. (1997).

[18] Compton, W. An Introduction to Postive Psychology. Unites States, America: Thompson Learning, Inc. (2005).

[19] Wong, P. T., \& Wong, L. C. Handbook of multicultural perspectives on stres and coping. New York: Springer Science+Business Media, Inc. (2006).

[20] Marsella, A. J., Wong, P. T., \& Wong, L. C. Handbook of Multicultural Perspectives on Stres and Coping. United States of America: Springer. (2006).

[21] Gravetter, F. J., \& Forzano, L.-A. B. Research Methods for The Behavioral Sciences. California: Wadsworth Publishing. (2011).

[22] Pargament, K. I., Koenig, H. G., \& Perez, L. M. The many methods of religious coping: Development and initial validation of the RCOPE. Journal of clinical psychology, 56(4), 519543. (2000).

[23] Cohen, S., \& Williamson, G. Perceive Stres in a Probability Sample of the United States. Dalam S. Spacapan, \& S. Oskamp, The Social Psychology of Health. Newbury Park, CA, Sage. (1988).

[24] McMahon, B. T., \& Biggs, H. C. Examining spirituality and intrinsic religious orientation as a means of coping with exam anxiety. (Vulnerable Groups \& Inclusion) Diambil kembali dari http://dx.doi.org/10.3402/vgi.v3i0.14918. (2012).

[25] Ellison, C. G., \& Taylor, R. J. Turning to prayer: Social and situational antecedents of religious coping among African Americans. Review of Religious Research, 31:111-131. (1996).

[26] Pargament, K. I. The Psychology of Religion an Coping: Theory, Research, and Practice. New York: The Guildford Press. (1997).

[27] Chen, Y. Y., \& Koenig, H. G. Traumatic stress and religion: Is there a relationship? A review of empirical findings. Journal of Religion and Health, 45(3), 371-381. (2006).

[28] Geertz, C. Religion as a Cultural System In Anthropological Approaches to the Study of Religion Ed Michael Bonton. (1996).

[29] Cohen, S., \& Williamson, G. Perceive Stres in a Probability Sample of the United States. Dalam S. Spacapan, \& S. Oskamp, The Social Psychology of Health. Newbury Park, CA, Sage. (1988).

[30] Pargament, K. I., Koenig, H. G., \& Perez, L. M. The many methods of religious coping: Development and initial validation of the RCOPE. Journal of clinical psychology, 56(4), 519543. (2000).

[31] Kliewer, W., \& Sandler, I. N. Locus of control and self-esteem as moderators of stressorsymtomps relations in children and adolescents. Jornal of Abnormal Child Psychology, 20, 393413. (1992).

[32] Kovel, J. Beyond the future of an illusion: Further reflections on Freud and religion. Psychoanalytic review, 77(1), 69-87. (1990).

[33] Papalia, Diane, E., Olds, Sally, W., \& Feldman, R. D. Human Development (8th ed.). Boston: McGraw Hill. (2001). 
[34] Cohen, S., \& Williamson, G. Perceive Stres in a Probability Sample of the United States. Dalam S. Spacapan, \& S. Oskamp, The Social Psychology of Health. Newbury Park, CA, Sage. (1988). 